\title{
Analysis of Sedimentary Environment Conditions for Lacustrine Fine-Grained Sedimentary Rocks and Its Control of Lithofacies Development: A Case Study of the Lower Submember of Member 3 of Shahejie Formation in FY-1 Well, Dongying Sag, Bohai Bay Basin, China
}

\author{
Jun Peng $\mathbb{D}^{1}{ }^{1}$ Ledan $Y u \mathbb{D}^{1},{ }^{1}$ Tianyu Xu, ${ }^{1}$ Yubin Wang, ${ }^{1}$ and Haodong Han ${ }^{2}$ \\ ${ }^{1}$ School of Geoscience and Technology, Southwest Petroleum University, Chengdu, Sichuan, 610500, China \\ ${ }^{2}$ Chengdu Geological Survey Center, China Geological Survey, Chengdu, Sichuan, 610081, China \\ Correspondence should be addressed to Ledan Yu; yldxsyhxs@126.com
}

Received 30 November 2020; Accepted 17 August 2021; Published 13 September 2021

Academic Editor: Julie Pearce

Copyright (c) 2021 Jun Peng et al. This is an open access article distributed under the Creative Commons Attribution License, which permits unrestricted use, distribution, and reproduction in any medium, provided the original work is properly cited.

In recent years, the studies on fine-grained sedimentation mainly focus on the rock type, sedimentary environment, sedimentation, and sequence stratigraphy, while those on the relationship between sedimentary environment and lithofacies development are rare. However, a clear understanding on the relationship is of great significance to the muddy shale oil and gas exploration. This paper studied the muddy shale of semideep and deep lacustrine facies in the lower submember of Member 3 of Shahejie Formation in FY-1 Well, Dongying Sag, Bohai Bay Basin, East China. Based on geochemical data, the sedimentary environment media conditions and vertical changes of this submember were analyzed by means of core description, thin section authentication, X-ray diffraction (XRD), and other technologies, and the relationship between sedimentary environment and lithofacies development was discussed. The results show that this environment underwent three stages and is featured by cyclicity. From the bottom up, it experienced the semideep, deep, and deep/semideep waters under the relatively dry-cold/relatively warm-wet, warm-wet, and warm-wet/relatively warm-wet paleoclimates, respectively. Correspondingly, the paleoredox transited three stages from reducibility to high reducibility to high reducibility/reducibility; the paleosalinity changed from saline water to brackish water to brackish/saline water. Paleoproductivity was low/relatively high at the beginning, then became high, and finally relatively high. In this submember, the lithofacies primarily includes organic-rich mudstone, organic-rich lime mudstone, organic-rich lime-bearing mudstone, and organic-contained argillaceous limestone/lime mudstone. The sedimentary environment controls the mineral composition and content in the lithofacies and thus determines the lithofacies types. Meanwhile, the cyclicity of environmental change not only leads to that of the lithofacies development but also affects the positions of the lithofacies and its assemblages in sequence stratigraphic framework.

\section{Introduction}

Fine-grained sediments refer to the clayey and silty ones with the diameter less than $62 \mu \mathrm{m}$, mainly containing pyrites, organic matters, and clay, felsic, and carbonate minerals $[1,2]$. The fine-grained sedimentary rock (also known as the muddy shale) is composed of fine-grained sediments, and it covers about two-thirds of the sedimentary rocks [3]. The organic-rich fine-grained rock in deep water is a crucial source rock and has become a key object in unconventional oil and gas exploration [3-7]. Many scholars' studies on fine-grained sedimentation have focused on mineral composition, rock type, sedimentary environment, and the properties of source-reservoir-cap assemblages of oil and gas [8-12]. Their achievements in the field have promoted the development of fine-grained sedimentology. However, it is still a worldwide scientific challenge to classify and describe the fine-grained sedimentary environment precisely due to 
the complex formation mechanism and various lithofacies types of these sediments. Besides, the relationship between this environment and the lithofacies is rarely studied. Thus, the environment cannot be analyzed rapidly and accurately according to lithofacies types. In view of this, it is essential to probe into its sedimentary environment media conditions and figure out its control effect on lithofacies development so as to lay a solid geological theory foundation for the unconventional muddy shale oil and gas exploration.

The sedimentological and geochemical indicators preserved in sedimentary strata can reflect the change of the sedimentary environment. Armstrong et al. and Yuri et al. studied the redox property and salinity by mineral composition and geochemical and palaeontological methods [13, 14]. Romero and Slatt and Rodriguez found that for fine-grained rocks in deep water, the hydrocarbon generation potential $\left(\left(S_{1}+S_{2}\right) / T O C\right)$ also reflected the water depth and redox property, and its content was positively correlated with the two factors [10, 15]. Guo et al. indicated that the climate changed with alternating wet and dry conditions in Member 3 of Hetaoyuan Formation in BY-1 Well of the Biyang Sag. The research region was divided into 7 high-frequency cycles according to four substitutive indicators, i.e., paleoclimate, paleosalinity, paleoproductivity, and paleoredox [16]. Pang et al. classified the lithofacies in the upper submember of Member 4 and the lower submember of Member 3 of Shahejie Formation in FY-1 Well into 11 types and divided the paleoenvironmental evolution of 6 stages [17]. Wang et al. studied the fine-grained sedimentary system of lacustrine shale through core description, thin section observation, and geochemical tests. It is considered that the mud shale from the upper submember of Member 4 and lower submember of Member 3 of Shahejie Formation in Jiyang depression is a product of the combined action of mechanical and biochemical mixed sedimentation under the relatively stable water environment [18]. Shi et al. combined sedimentological and geophysical methods such as field section measurements, core analyses, well logs, and seismic section interpretation to study the sedimentary evolution from the middle Permian to the early Triassic. In addition, provenance analysis was performed for the sediments from both flanks of the Bogda Mountain [19]. Shi et al. used the outcrops in the north rim of the Bogda Mountain, cores, seismic, drilling, and logging data of the Fukang and Jimusar sag to illuminate the middle Permian-lower Triassic stratigraphic distribution, characteristics of sedimentary facies, and climate change in the Bogda region. Based on the above research, a tectono-climate-sedimentary evolution of the middle Permian to early Triassic can be rebuilt [20]. Previous research has been centered on the mineral composition, rock type, and sedimentary environment [8-12], of which the third one is studied mostly based on geochemical indicators rather than sedimentological ones. Besides, there are rare studies on the relationship between this environment and the lithofacies. Therefore, the sedimentological and geochemical indicators, which are sensitive to the sedimentary environment, were used in this paper comprehensively to clarify the characteristics of this environment and its control of lithofacies development, which will be helpful to further understand the sedimentary rule of fine-grained sedimentary rocks.

There is a large set of such rocks in the Paleogene Shahejie Formation, Dongying Sag, Bohai Bay Basin, where the oil and gas resources are abundant, showing a high exploitation level [17, 21-23]. Meanwhile, the rock cores from cored wells and the test materials (thin sections, XRD, elements, and organic geochemistry) are complete, making it the best region to study the sedimentary environment and its relationship with lithofacies development. In recent years, scholars have made great progress in this set of finegrained sedimentary rocks, which promotes shale oil and gas exploration. However, rare studies are conducted on the environment of fine-grained lacustrine rocks whose lithology changes frequently and its control of the lithofacies. Based on previous studies, the lower submember of Member 3 of Shahejie Formation in FY-1 Well of the Dongying Sag was taken for an example in this paper to analyze the sedimentary environment media conditions and vertical changes, discuss the relationship between sedimentary environment and lithofacies development, and clarify the control mechanism of this environment on different lithofacies types. Technical methods including core observation, thin section authentication, and XRD were utilized in combination with information such as sedimentological indicators and geochemical analysis. The research achievements are conductive to the unconventional muddy shale oil and gas exploration, showing a theoretical significance to the finegrained sedimentology.

\section{Geological Setting}

\subsection{Structural-Sedimentary Evolution Characteristics. Bohai} Bay Basin is located in East China. It is a MesozoicCenozoic fault basin that developed in North China Plate after Paleozoic Sedimentation and Movements during Indosinian and Yanshan periods (Figures 1(a) and 1(b)) [24-26]. Jiyang depression locates in the southeast of this basin and developed four secondary sags, i.e., Chezhen Sag, Zhanhua Sag, Huimin Sag, and Dongying Sag (Figure 1(c)) [24]. Its structural evolution characteristics have been inherited by the Dongying Sag. Through multistage structural movements, the bottom of this sag develops the pre-Mesozoic basement, the middle is the layer forming in the rift stage, and the top is the one forming in the depression stage. The fault-depression stage of the structural evolution of this sag occurred in Paleogene. It is the primary extensional faulting stage when many extensional faults are developed with intense movements. Thus, a typical asymmetric dustpanshaped sagged is formed into many salients developing around it. It is "faulted and steep in the north, and overlapped and gentle in the south." A series of synsedimentary normal faults of the sag further divide it into four petroleums generating subsags (Boxing, Lijin, Niuzhuang, and Minfeng) and the northern steep slope zone, central anticlinal zone, southern gentle slope zone, and various fault structure zones and other secondary structural units (Figure 1(d)) [26-29]. 


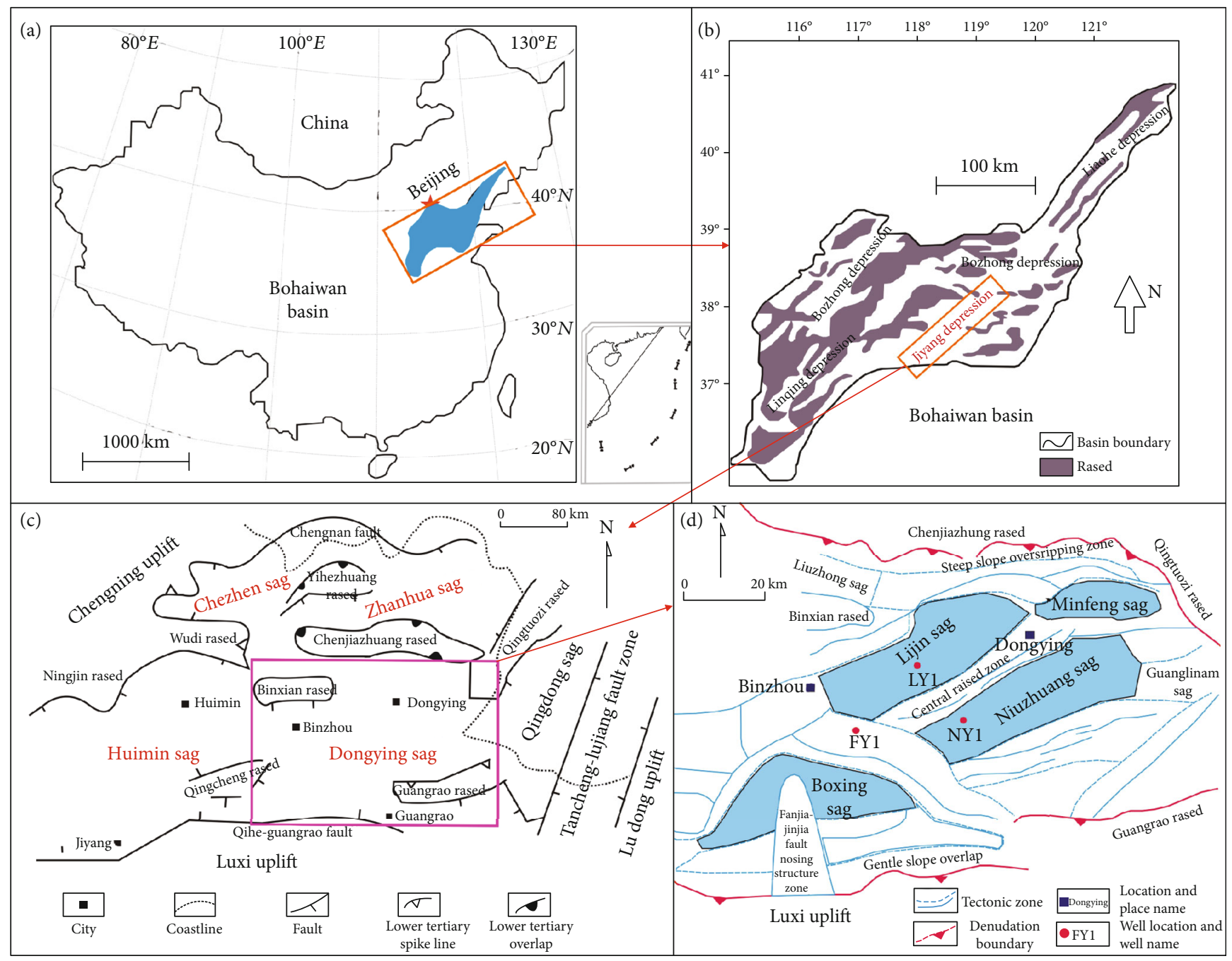

Figure 1: (a) Location of Bohai Bay Basin in northern China (revised by [24-26]); (b) schematic diagram of tectonic zone of Bohai Bay Basin (revised by [24, 26]); (c) regional location and schematic diagram of tectonic zone of Jiyang depression (revised by [24]); (d) well position chart and schematic diagram of tectonic zone of Dongying Sag (revised by [26-29]).

2.2. Stratum Development Characteristics. The Dongying Sag has developed Paleozoic $(\mathrm{Pz})$, Mesozoic $(\mathrm{Mz})$, Eocene $(\mathrm{E})$, Neogene $(\mathrm{N})$, and Quaternary (Q) strata from bottom to top. Thereinto, the Eocene stratum is widely distributed, with a thick sedimentary layer. The thickest part is over 7 kilometers, but it is gradually thinned and sharpened from the center of the edge. From the bottom to the top, this stratum is divided into Kongdian Formation, Shahejie Formation, and Dongying Formation, of which the Shahejie Formation includes 4 members, as shown in Figure 2 [24, 30-32]. Member 3 is characterized by the lacustrine sedimentation of dark gray and gray muddy shales, with the thickness of 700-1,000 m. The middle part is as thick as 1,200 $\mathrm{m}$ or above. This member is further divided into the lower, middle, and upper submembers from bottom to top. The lower one develops the deep lacustrine sedimentation of dark gray mudstone, oil shale, and grayishbrown oil shale that are interbedded in unequal thick, with a small amount of thin sand, gray limestone, and dolomite (Figure 2). The stratum of this member records how the lake environment and climate change, so it is an ideal region to study the sedimentary environment.

\section{Data and Experimental Methods}

Rock core analysis by X-ray fluorescence (XRF): the rock core located in the depth of 3,052-3,251 $\mathrm{m}$ in the lower submember of Member 3 of Shahejie Formation in FY-1 Well was elaborated, and its element content was tested by the NITON XL3t-950 Handheld Mineral Element Analyzer (an instrument based on the XRF spectral analysis technology) developed by Thermo Scientific [33]. In order to ensure the data validity, the test points were spaced $2.5 \mathrm{~cm}$ apart according to the Nyquist sampling theorem, with each one taking $20 \mathrm{~s}$ [34]. In this test, mineral and soil models were adopted to measure different element contents. The former was used for major elements, while the latter was used for trace ones with the content less than $1 \%$. This study tested Ti, Si, S, K, Ca, Fe, V, Ba, Zr, Mn, Zn, etc., to analyze the 


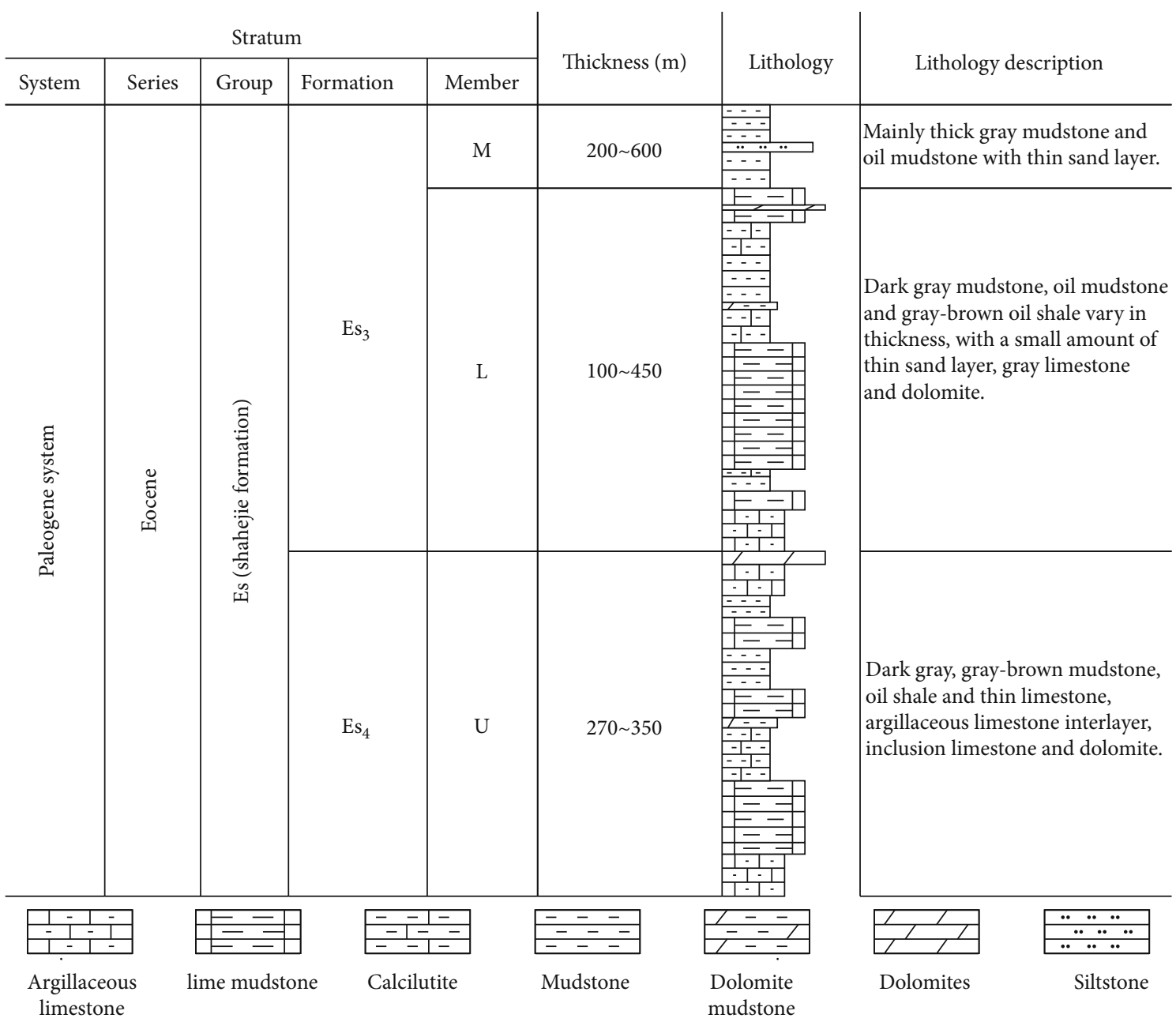

FIgURE 2: Characteristics of stratum development in Dongying Sag, Jiyang depression (revised by [24, 30-32]).

paleoenvironment and classified the element indicators representing the paleoclimate, paleowater depth, paleosalinity, paleoredox, and paleoproductivity in the test data [16].

Whole-rock analysis by $\mathrm{X}$-ray diffraction (XRD): this is a common method to determine the mineral composition of rocks. Firstly, the rock samples were ground into grains in the size of about $5 \mu \mathrm{m}$ or less than 200 mesh. Secondly, they were pressed and moulded and then tested to obtain the mass percentage of minerals. The TTR X-ray diffractometer manufactured by Rigaku Corporation, Japan, was adopted for the XRD test according to the industrial standard of SY/T 5163-2010 [34-36].

Total organic carbon (TOC) analysis: the dry samples were ground into grains with a diameter of $0.2 \mathrm{~mm}$, and the diluted hydrochloric acid (pure hydrochloric acid: water $=1: 7$ ) was used to remove the inorganic carbon components. Then, these samples were burned in the hightemperature oxygen fluid (oxygen purity: 99.9\%) to convert the TOC into carbon dioxide. Finally, based on the corresponding relation of carbon content between TOC and carbon dioxide, the content of the latter was detected by an infrared/thermal conductivity detector, and that of the former was calculated accordingly. The LECOCS-230 Carbon
Sulfur Analyzer was used in this test, and the test conditions refer to the national standard of GB/T 19145-2003 [34-36].

\section{Results and Discussion}

4.1. Paleoenvironmental Analysis. Elements, which are prevalent in various sediments, are extremely sensitive to environmental change. Their migration and enrichment rules are affected by the geological environment [37]. However, petrological and other sedimentological indicators can also reflect sensitively the condition when the sediments are formed in the lake basin [38-40]. Therefore, based on the sedimentological and geochemical indicators that reflect the lacustrine sedimentation, this paper analyzed the paleoenvironment from paleoclimate, paleowater depth, paleoredox, paleosalinity, and paleoproductivity and discussed the control effect of sedimentary environment on lithofacies development.

4.1.1. Paleoclimate. Sedimentological indicators, such as color, lithology, mineral composition, and sedimentary structure $[40,41]$, and geochemical ones, for example, the $\mathrm{Na} / \mathrm{Al}[17,27,41-43]$ and dry-wet index C $\left(\mathrm{C}=\sum(\mathrm{Fe}+\mathrm{Mn}+\mathrm{Cr}+\mathrm{V}+\mathrm{Co}+\mathrm{Ni}) / \sum(\mathrm{Ca}+\mathrm{Mg}+\mathrm{Sr}+\mathrm{Ba}+\mathrm{K}+\mathrm{Na})\right)$ 
$[40,44,45]$, are sensitive to the paleoclimate and thus used for the analysis.

The change of substitutive indicators for the paleoclimate in the lower submember of Member 3 of Shahejie Formation in FY-1 Well is featured with periodicity and cyclicity. Firstly, in the stage of 3,169.15-3,251 m (Stage 1, the same in the following), the light gray-gray organic-contained argillaceous limestone is developed at the bottom, with the rock core becoming gray-dark gray upward. Besides, there is a higher proportion of dark gray lime mudstone that reflects the deepening of water body. The wave structure of the calcite is occasionally seen, interbedded with a large number of arenites composed of micritic calcite [37, 46, 47]. The sedimentary structure is dominated by the flat lamina. The $\mathrm{Na} / \mathrm{Al}$ value is high, showing a decreasing trend from bottom to top, while the dry-wet index $(\mathrm{C})$ is low (with a mean value of 0.4 ), showing an increasing trend along the same direction. Besides, the calcite content is high (1\%-77\%), with an average value of $42.92 \%$, but it tends to decline in this direction. The contents of clay mineral (3\%-52\%) and quartz (5\%-36\%) are low. Their mean values are $18.85 \%$ and $21.79 \%$, respectively, showing an increasing trend. Based on the above changes, it is speculated that the environment is relatively dry and cold in this stage due to the arid climate in the upper submember of Member 4 of Shahejie Formation, but it became relatively warm and wet from the bottom up (Figures 3 and 4). Secondly, in the stage of 3,086.55-3,169.15 $\mathrm{m}$ (Stage 2, the same in the following), the rock core is dark gray, and the lithological characters mainly include lime mudstone, lime-bearing mudstone, and mudstone, with the massive and stratified structures developed. There are more organic matters in this stage. Meanwhile, the $\mathrm{Na} / \mathrm{Al}$ value keeps decreasing, while the $\mathrm{C}$ value increases to 0.6. As for the mineral composition, the calcite content, ranging from $2 \%$ to $74 \%$, shows the same trend as in Stage 1, but its mean value decreases to $36.1 \%$. The contents of clay mineral (3\%-59\%) and quartz (10\%-45\%) increase, with their mean values rising to $25.47 \%$ and $23.95 \%$, respectively. As shown by the change of these indicators, the climate is warm and wet in this stage (Figures 3 and 4 ). Finally, in the stage of 3,051-3,086.55 $\mathrm{m}$ (Stage 3, the same below), the rock core remains dark gray, and the lime-bearing mudstone and lime mudstone are formed. The sedimentation develops from massive structure to laminated one. In this stage, the organic matter content is still high. There is a little increase in the $\mathrm{Na} / \mathrm{Al}$, while the $\mathrm{C}$ value decreases to 0.5 . The average content of calcite increases slightly to $36.64 \%$, and those of clay mineral and quartz decrease to $24.91 \%$ and $19.87 \%$, respectively. It is found from these changes that the climate remains warm and wet in Stage 3 and will become relatively warm and wet gradually (Figures 3 and 4 ).

According to the variation trend of sedimentological and geochemical indicators in this submember, the paleoenvironment undergoes the relatively dry-cold/relatively warmwet climate in Stage 1, the warm-wet climate in Stage 2, and the warm-wet/relatively warm-wet climate in Stage 3.

4.1.2. Paleowater Depth. The water depth is studied based on geochemical indicators, including $\mathrm{Th} / \mathrm{U}, \mathrm{Fe} / \mathrm{Mn},(\mathrm{Fe}+$ $\mathrm{Al}) /(\mathrm{Ca}+\mathrm{Mg})$, and $\mathrm{TOC}$, and sedimentological ones, such as color, lithology, and mineral composition (pyrite, carbonate mineral, and quartz) $[15,17,27,40,41,43,44,48-51]$.

In the lower submember of Member 3 of Shahejie Formation, the change of substitutive indicators for the paleowater depth is characterized by phasing and cyclicality. In the first stage, the relatively dry and cold climate becomes relatively warm and wet, and the light gray-gray rock core turns dark. The lithology is mainly the lime mudstone, and the sedimentary structure is characterized by the flat lamina. The contents of pyrite and TOC are low, and the mean value of the former is merely $2.37 \%$. However, there is an increasing trend for them from bottom to top. The ratios of element associations, such as $\mathrm{Fe} / \mathrm{Mn}$ and $(\mathrm{Fe}+\mathrm{Al}) /(\mathrm{Ca}+\mathrm{Mg})$, are high and tend to decline when going upward. Therefore, the water is shallow in this stage, but it becomes deeper slightly in the upward direction (Figures 3 and 4). Secondly, the climate is warm and wet in Stage 2, and the rock core is mainly dark gray. Besides, the massive and stratified structures are developed, with a higher shaliness. The pyrite content continues to increase steadily, with its mean value rising from $2.37 \%$ in Stage 1 to $3.4 \%$ in this stage. The TOC content is stable, and the ratios of element associations reduce to a lower level. It can be seen from the change of all indicators that the water is deep in this stage (Figures 3 and 4). Finally, the climate becomes relatively warm and wet in the third stage. However, it is warm and wet on the whole. The rock core is mainly dark gray-gray. The sedimentation develops from a massive structure to a laminated one, with the shaliness increasing. The average pyrite content is $3.11 \%$, and the TOC content is comparatively high. The association ratios of $\mathrm{Fe} / \mathrm{Mn}$ and $(\mathrm{Fe}+\mathrm{Al}) /(\mathrm{Ca}+\mathrm{Mg})$ increase slightly. These changes indicate that the water remains deep in this stage after the deepening in the previous one (Figures 3 and 4 ).

As shown by the changes of all the above indicators, the water depth evolves through 3 stages in the lake basin of the lower submember. In the first stage, there are little freshwater flows from rivers into the basin and a relatively dry/relatively warm-wet climate caused the low precipitation. Meanwhile, the water evaporates significantly, resulting in the decrease in the inflow, and the increases in drainage. Thus, the water is shallow, but it will become deep upward. The climate is warm and wet in the second stage when the water depth increases rapidly to its maximum. In the third stage, the water is still deep when the climate becomes relatively warm and wet.

4.1.3. Paleoredox. The paleoredox condition is a crucial factor affecting the preservation of organic matters, and indicators for its study include geochemistry and sedimentological indicators such as color and mineral composition [13, 14]. In this paper, geochemical indicators, $\mathrm{V} / \mathrm{Cr}, \mathrm{Ni} / \mathrm{Co}, \mathrm{V} /$ $(\mathrm{V}+\mathrm{Ni})$, and TOC, and sedimentological indicators, color and pyrite, were adopted for its study $[15,17,27,40-43$, $45,49,52-63]$.

The change of all indicators for the paleoredox in the lower submember of Member 3 of Shahejie Formation is periodic and cyclic. In the first stage, the relatively dry and cold climate becomes relatively warm and wet, and the water 


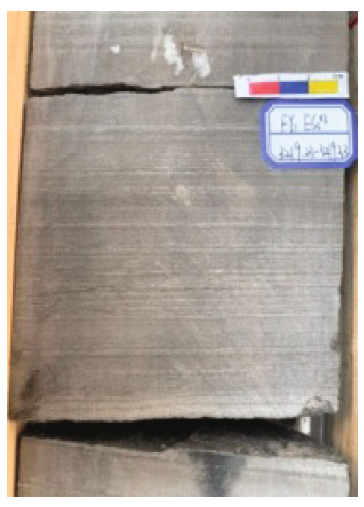

(a)

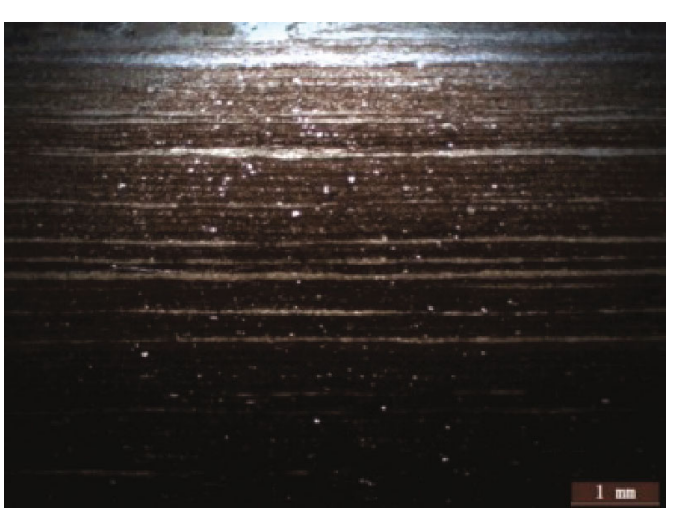

(c)

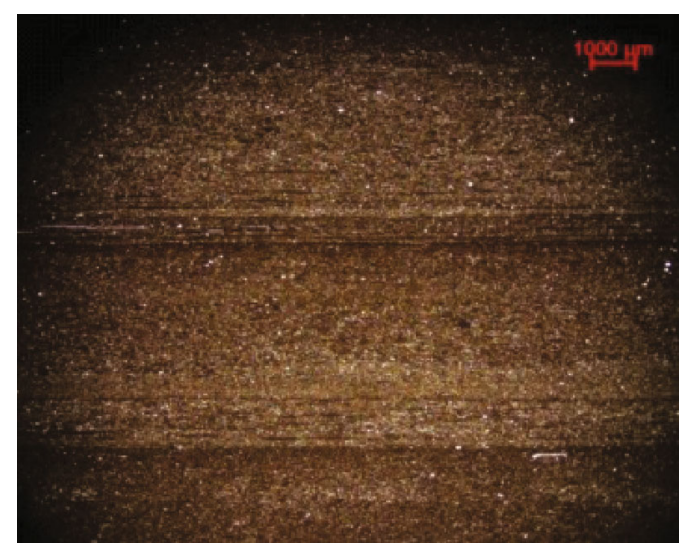

(e)

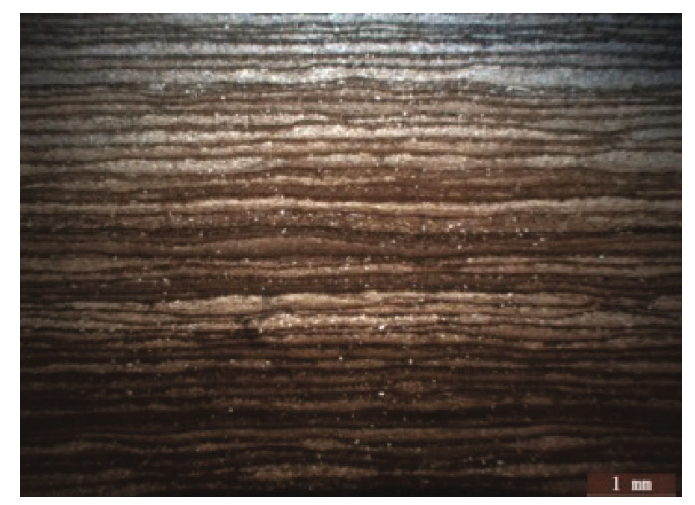

(b)

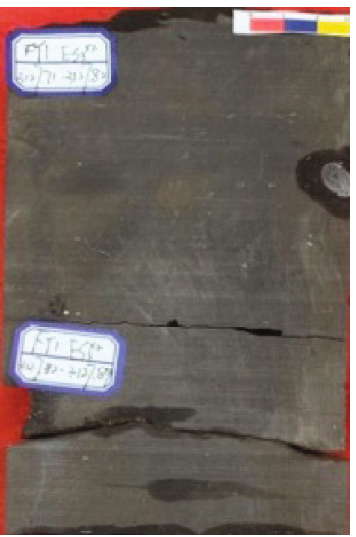

(d)

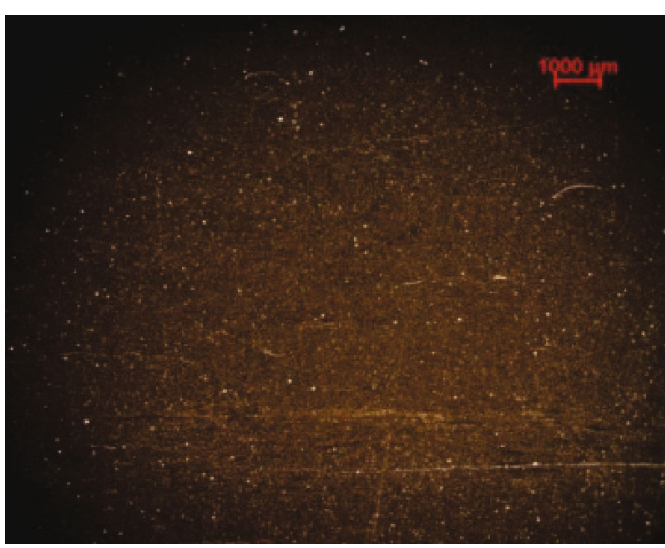

(f)

Figure 3: Continued. 


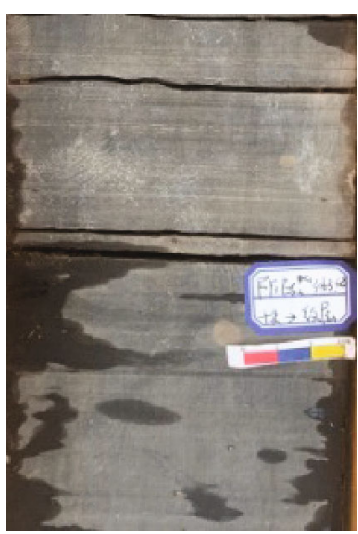

(g)

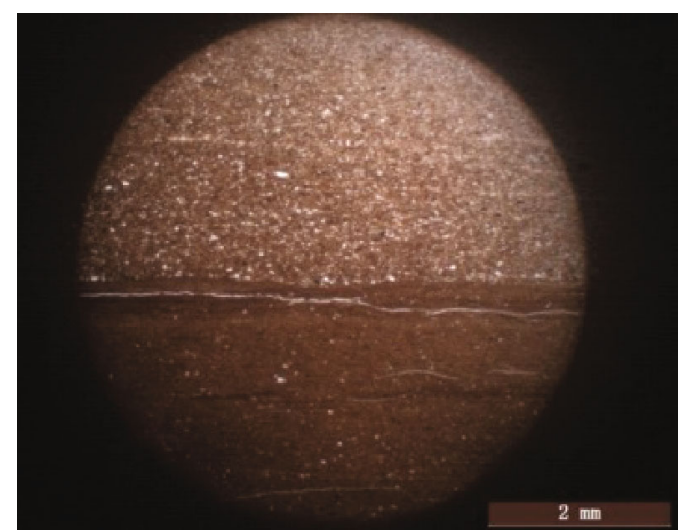

(h)

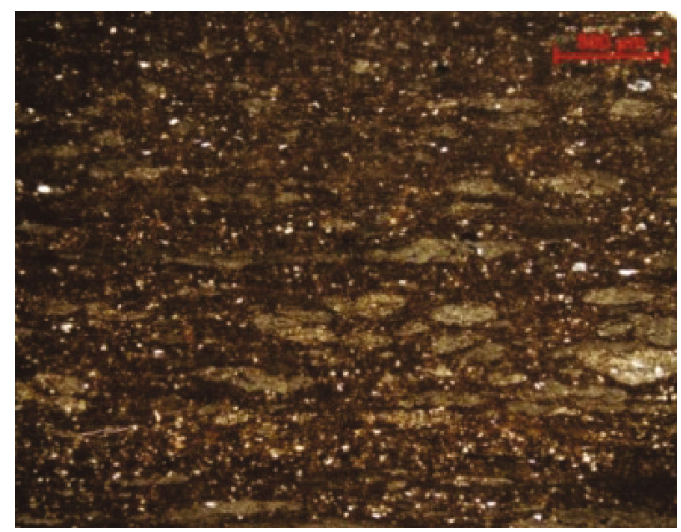

(i)

FIGURE 3: Development characteristics of fine-grained sedimentary rocks in the lower submember of Member 3 of Shahejie Formation in FY-1 Well of the Dongying Sag: (a) organic-contained lime mudstone, flat lamina, clear boundary between lime and argillaceous laminae, FY-1 Well, 3,219.23 3,219.33 m; (b) organic-contained argillaceous limestone, flat lamina, the lime lamina is thicker than argillaceous one, FY-1 Well, 3,248.44 m; (c) organic-rich lime mudstone, flat lamina, the argillaceous lamina is thicker than lime one, FY-1 Well, 3,181.17 m; (d) organic-rich lime-bearing mudstone, massive structure, FY-1 Well, 3,127.71 3,128.03 m; (e) organic-rich lime-bearing mudstone, stratified structure, FY-1 Well, 3,176.13 m; (f) organic-rich mudstone, massive structure, testa fragments, FY-1 Well, 3,123.24 m; (g) organic-contained lime mudstone, from massive structure to laminated one, FY-1 Well, 3,063.68 m; (h) from organic-rich mudstone to silty claystone, massive structure, bedded testa fragments, FY-1 Well, 3,086.12 m; (i) organic-rich lime-sand mudstone, massive structure, a large amount of arenites composed of micritic calcite, FY-1 Well, 3,080.25 m.

is shallow. The rock core is mainly light gray-gray, with a low TOC content. In this stage, the pyrite content decreases, with a mean value of $2.37 \%$. However, it tends to rise from the bottom up. The association ratios of $\mathrm{V} / \mathrm{Cr}, \mathrm{Ni} / \mathrm{Co}$, and $\mathrm{V} /(\mathrm{V}+\mathrm{Ni})$ are low, with their average values being 3.43, 5.02 , and 0.48 , respectively. These indicators show that this stage is characterized by a weak reducing/reducing environment. Secondly, the climate is warm and wet, and the water is comparatively deep in Stage 2. In addition to a high TOC value, the pyrite content continues to increase steadily, and its mean value rises from $2.37 \%$ in Stage 1 to $3.4 \%$ in Stage 2. The above association ratios keep increasing to $4.52,7.27$, and 0.69 , respectively. It can be seen from this that the water is deeper in this stage, showing a strong reducing environment. Finally, in the third stage, the climate is unchanged, and the water remains deep. The content of TOC is still high, and that of the pyrite is $3.11 \%$ averagely. The ratios of $\mathrm{V} / \mathrm{Cr}$, $\mathrm{Ni} / \mathrm{Co}$, and $\mathrm{V} /(\mathrm{V}+\mathrm{Ni})$ reduce to $4.17,5.63$, and 0.50 , respectively. According to these changes, this stage is in a strong reducing/reducing environment (Figures 3 and 5).

The variation of these indicators shows how the water body in the lake basin changes with the redox property in the lower submember of Member 3 of Shahejie Formation. Firstly, there is little river water flowing into the basin due to the low precipitation under an arid climate. In addition, evaporation is significant. Consequently, the water inflow is lower than the drainage. Thus, the water becomes shallow, showing a low reducibility. After this arid climate, the precipitation and water inflow increase slightly. The pyrite content is also a little higher, indicating a gradual increase in water depth and reducibility. Then, the climate becomes warm and wet, resulting in the deepest water and the highest reducibility. However, after entering a relatively warm-wet climate in the third stage, both the depth and the reducibility decline. In conclusion, the redox property goes through 3 stages that are characterized by weak reducing/reducing 


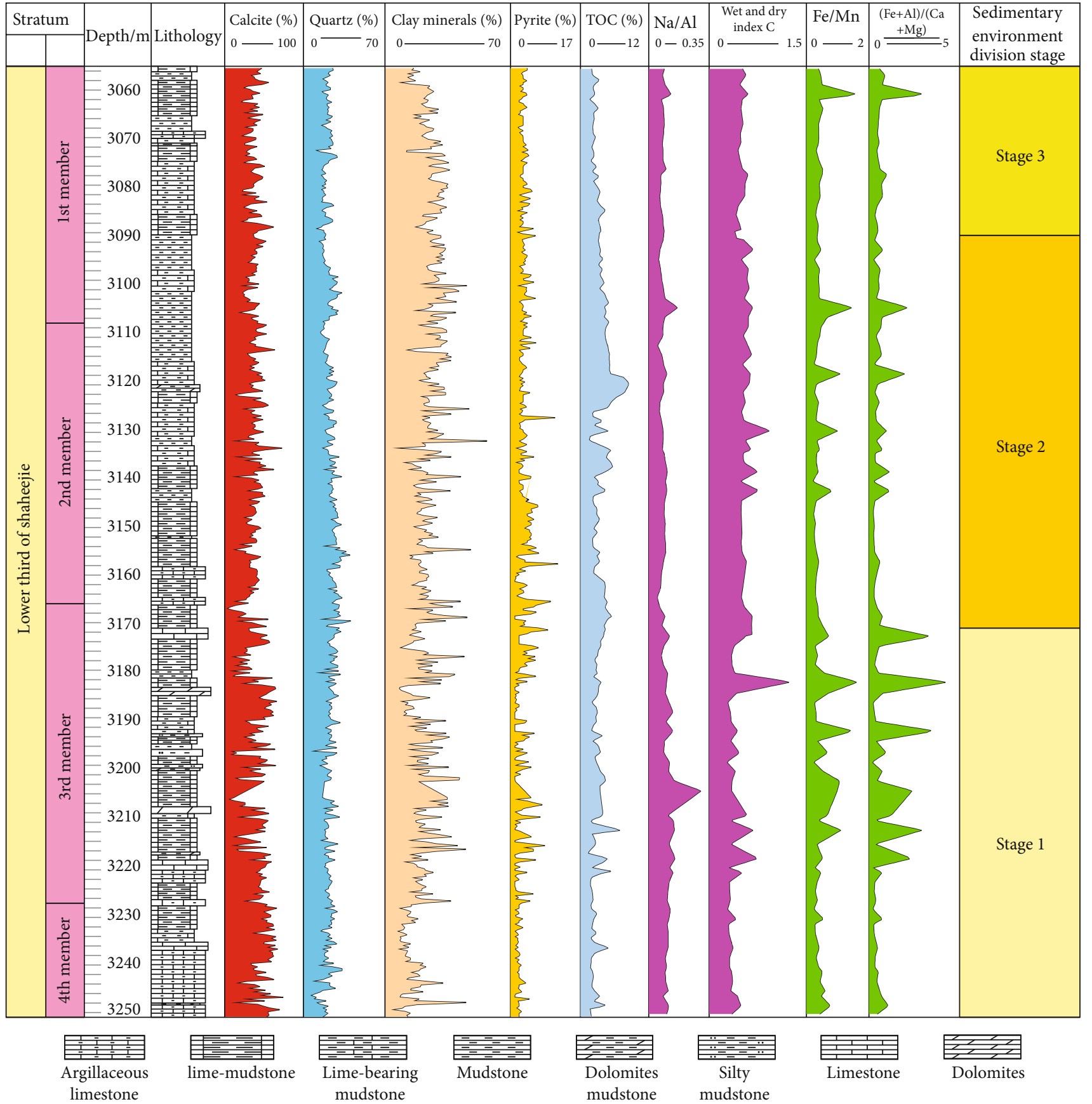

Figure 4: Analysis results of the paleoclimate and paleowater depth in the lower submember of Member 3 of Shahejie Formation in FY-1 Well.

water, strong reducing water, and strong reducing/reducing water, respectively.

4.1.4. Paleosalinity. The paleosalinity in this paper is analyzed by geochemical indicators of $\mathrm{Sr} / \mathrm{Ba}$ and $\mathrm{Ca} /(\mathrm{Ca}+\mathrm{Fe})$, and dolomite content $[17,40-45,50,61,64-69]$.

The change of all indicators for the paleosalinity in the lower submember of Member 3 of Shahejie Formation presents the periodicity. The first stage shows a high water salinity under a relatively dry/relatively warm-wet climate. $\mathrm{The} \mathrm{Sr} / \mathrm{Ba}$ is high, its maximum value is 7.28 , and its average value is 2.61. It tends to increase from the bottom up. As for $\mathrm{Ca} /(\mathrm{Ca}+\mathrm{Fe})$, its maximum and mean values are 0.93 and 0.79 , respectively. The dolomite content is high, ranging between $1 \%$ and $46 \%$, and its average value is $8.05 \%$. It can be known from these indicators that this stage is in a saline water environment with a high salinity. Secondly, the climate is warm and wet, and the water is deepest in Stage 2. $\mathrm{The} \mathrm{Sr} / \mathrm{Ba}$ reduces to the lowest level, with an average value of 1.00 . The $\mathrm{Ca} /(\mathrm{Ca}+\mathrm{Fe})$ decreases to 0.73 on average. Meanwhile, the dolomite content that is low in this stage ranges from $1 \%$ to $25 \%$, and its mean value reduces to 




Figure 5: Analysis results of the paleoredox, paleosalinity, and paleoproductivity in the lower submember of Member 3 of Shahejie Formation in FY-1 Well.

$6.48 \%$. These changes indicate that it is a brackish water environment with a low salinity. Finally, in the third stage, the climate is still warm and wet. The average values of $\mathrm{Sr} / \mathrm{Ba}$ and $\mathrm{Ca} /(\mathrm{Ca}+\mathrm{Fe})$ increase slightly to 1.48 and 0.8 , respectively. The dolomite content is higher than that in Stage 2, ranging between $1 \%$ and $36 \%$, and its mean value rises to $6.58 \%$. The change of all the above indicators shows that the salinity increases slightly in this stage, but the general variation is not obvious. Thus, it is a saline/brackish water environment (Figure 5).

As shown by these indicators, there are 3 stages for the salinity variation in the lower submember. In Stage 1 when the climate is relatively dry and cold, the salt is separated out due to the evaporation, resulting in a high salinity. Later, the climate becomes relatively warm and wet, and the salinity reduces slightly. In Stage 2 under a warm-wet climate, the water is deepest, and the salinity keeps reducing. At last, the climate becomes relatively warm and wet in Stage 3. Despite the slight increase in salinity, its overall level is still low.

4.1.5. Paleoproductivity. Paleoproductivity refers to the rate at which organisms fix the energy during the energy cycle in geologic history. It indicates the initial mass of organic matters in marine or lake bottom sediments. In this paper, 
TABle 1: The sedimentary environment media conditions and lithofacies assemblages in the lower submember of Member 3 of Shahejie Formation in FY-1 Well of the Dongying Sag.

\begin{tabular}{lcccccc}
\hline Stage & Paleoclimate & Paleowater depth & Paleosalinity & Paleoredox & Paleoproductivity & Lithofacies assemblages \\
\hline Stage 1 & $\begin{array}{c}\text { Relatively dry and } \\
\text { cold-relatively } \\
\text { warm and wet }\end{array}$ & Semideep water & Saline water & $\begin{array}{c}\text { Low } \\
\text { reducibility/ } \\
\text { reducibility }\end{array}$ & $\begin{array}{c}\text { Low/relatively } \\
\text { high }\end{array}$ & $\begin{array}{c}\text { Organic-contained argillaceous } \\
\text { limestone/lime mudstone, organic- } \\
\text { rich lime mudstone }\end{array}$ \\
\hline Stage 2 & Warm and wet & Deepwater & Brackish water & $\begin{array}{c}\text { High } \\
\text { reducibility }\end{array}$ & High & $\begin{array}{c}\text { Organic-rich mudstone, organic- } \\
\text { rich lime-bearing mudstone, } \\
\text { organic-rich lime mudstone }\end{array}$ \\
\hline Stage 3 & $\begin{array}{c}\text { Warm and wet- } \\
\text { relatively warm } \\
\text { and wet }\end{array}$ & Deep/semideep water & $\begin{array}{c}\text { Saline/ } \\
\text { brackish water } \\
\text { reducibility/ } \\
\text { reducibility }\end{array}$ & Relatively high & $\begin{array}{c}\text { Organic-rich lime-bearing } \\
\text { mudstone, organic-rich lime } \\
\text { mudstone }\end{array}$ \\
\hline
\end{tabular}

it is analyzed based on geochemical indicators, such as $\mathrm{Ba}$, $\mathrm{Ba} / \mathrm{Al}, \mathrm{Al} / \mathrm{Ti}$, and TOC $[16,50]$, and sedimentological indicators, including color, lithology, and sedimentary structure.

In the lower submember of Member 3 of Shahejie Formation, the indicators for the paleoproductivity change periodically. In Stage 1, the rock core is mainly light gray-gray, with a low TOC content. The organic-contained argillaceous limestone is formed at the bottom, and the dark gray lime mudstone that reflects the deepening of the water body is developed upward. The sedimentary structure is mainly the flat lamina. In the meantime, the $\mathrm{Ba}$ is $226.24-933.81 \mu \mathrm{g} / \mathrm{g}$, with the average value being $517.94 \mu \mathrm{g} / \mathrm{g}$. It is lower at the bottom, but it increases upward. The ratio of $\mathrm{Ba} / \mathrm{Al}$ varies in the same way. As for $\mathrm{Al} / \mathrm{Ti}$, the ratio reduces slightly first and then increases, ranging between 10 and 24.71. Its mean value is 19.29. This means that the paleoproductivity increases gradually in this stage. In Stage 2, the rock core is dark gray, and the lime-bearing mudstone and mudstone are formed. The sedimentation mainly develops massive and stratified structures, with an increasing number of organic matters. Besides, the $\mathrm{Ba}$ value tends to be stable between $390 \mu \mathrm{g} / \mathrm{g}$ and $749.7 \mu \mathrm{g} / \mathrm{g}$, and its mean value is $611 \mu \mathrm{g} / \mathrm{g}$. The ratio of $\mathrm{Ba} / \mathrm{Al}$ shows the same trend, while that of $\mathrm{Al} / \mathrm{Ti}$ remains high and stable, with an average value of 20.45. In this stage, the productivity is high. Finally, the rock core is still dark gray, and the lime-bearing mudstone and lime mudstone are developed in Stage 3. The massive structure changes into laminated one. There are still a large number of organic matters. The mean value of $\mathrm{Ba}$ reduces to $528.66 \mu \mathrm{g} / \mathrm{g}$, and that of $\mathrm{Al} / \mathrm{Ti}$ is 20.21 . The paleoproductivity remains high in this stage (Figures 3 and 5).

According to the change of all indicators for the paleoproductivity in the lower submember of Member 3 of Shahejie Formation, the values only change slightly, except those that are low at the bottom. Meanwhile, the paleoproductivity is highest in Stage 2. Therefore, its evolution is divided into Stage 1 when the paleoproductivity is low/relatively high, Stage 2 when it is high, and Stage 3 when it is relatively high.

4.1.6. Analysis Results of Paleoenvironment. The paleoenvironment in the lower submember of Member 3 of Shahejie Formation in FY-1 Well of the Dongying Sag is analyzed from paleoclimate, paleowater depth, paleoredox, paleosalinity, and paleoproductivity based on geochemical and sedi- mentological indicators. Thereinto, the former includes $\mathrm{Na} / \mathrm{Al}$, dry-wet index (C), TOC, $\mathrm{Fe} / \mathrm{Mn},(\mathrm{Fe}+\mathrm{Al}) /(\mathrm{Ca}+$ $\mathrm{Mg}), \mathrm{V} / \mathrm{Cr}, \mathrm{Ni} / \mathrm{Co}$ and $\mathrm{V} /(\mathrm{V}+\mathrm{Ni}), \mathrm{Sr} / \mathrm{Ba}, \mathrm{Ca} /(\mathrm{Ca}+\mathrm{Fe}), \mathrm{Ba}$, and $\mathrm{Ba} / \mathrm{Al}$. The latter includes color, lithology, sedimentary structure, and mineral composition (clay mineral, calcite, dolomite, pyrite, and quartz). The results show that the sedimentary environment media conditions undergo 3 stages in FY-1 Well (Figures 4 and 5).

4.2. The Control Effect of Sedimentary Environment on the Lithofacies. The sedimentary environment media conditions affect the rock color, lithology, sedimentary structure, mineral composition, and geochemical components and thus determine the different development positions of the lithofacies and its assemblages in strata [66-77]. According to the vertical changes of sedimentological and geochemical indicators, this environment evolves through 3 stages in the lower submember of Member 3 of Shahejie Formation in FY-1 Well. Its control effect on the lithofacies is summarized based on the paleoenvironmental analysis in each stage (Table 1 and Figure 6).

Stage $1(3,169.15-3,251 \mathrm{~m})$ : there is low precipitation under an arid climate, so the water flowing into the lake basin is limited. The evaporation is greater than the inflow, resulting in shallow water. Thus, the relatively closed lake basin is formed. When the terrigenous input is low and the water salinity is high, a large number of saline minerals will be separated out, which is conducive to the development of the limestone. However, high-salinity water is harmful to organisms. For example, there will be fewer algae, and they can hardly be preserved, causing low lake productivity. Moreover, in the shallow lake, the reducibility is low, and the oxygen is sufficient at the bottom, which adverses to the generation and preservation of organic matters. Accordingly, the contents of them and the pyrite are low. Therefore, the light gray-gray organic-contained argillaceous limestone and lime mudstone are formed in this stage, and the sedimentary structure is characterized by the flat lamina. When the climate becomes warm and wet, the precipitation and water inflow increase. In the meantime, the water depth and terrigenous input also increase gradually. The lake basin becomes open. At this time, there are more clay minerals, and organic matters can be generated and preserved in a better way in the deep water. Hence, this stage has an increasing 


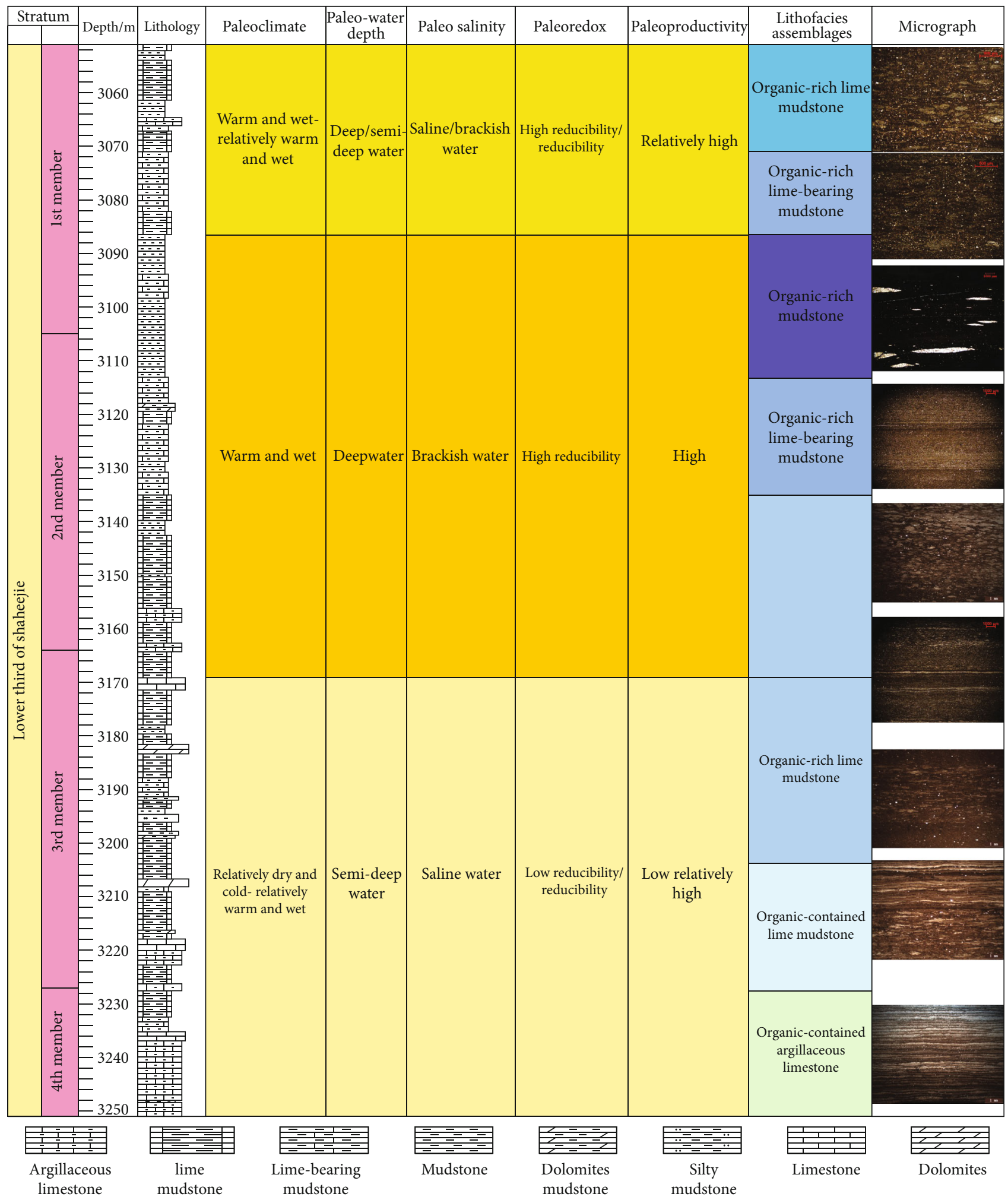

FIGURE 6: Sedimentary environment media conditions and lithofacies assemblages in the lower submember of Member 3 of Shahejie Formation in FY-1 Well of the Dongying Sag.

amount of dark gray rocks that reflect the gradual deepening of the water body. The sedimentation changes towards the massive structure, and the organic-rich lime mudstone is formed at the same time.
Stage $2(3,086.55-3,169.15 \mathrm{~m})$ : after the climate becomes warm and wet, the water is deepest due to the increasing amount of precipitation and terrigenous clasts. Meanwhile, the paleosalinity reduces, showing a high reducibility. In 
addition to the low salinity, terrigenous nutrients are also helpful to the growth of aquatic organisms. Thus, the algae and other organisms can thrive, causing a high biological productivity. When the oxygen in the water is consumed, the reducibility will be further enhanced. In the meantime, the lake stratification occurs in this stage. That is, the upper part contains sufficient oxygen, while the lower one is under oxidizing or oxygen-deficient condition. The lake bottom is in a strong reducing environment, in which the pyrite is developed most and the organic matters are preserved best. Besides, the water environment is generally calm. In this stage, the dark gray lime mudstone, lime-bearing mudstone, and mudstone are formed, but the carbonate minerals are developed poorly. As the sedimentation can hardly be affected by climate seasonally, there are many massive structures and some stratified ones. Therefore, this stage mostly develops the organic-rich lime-bearing mudstone and mudstone, with a small amount of organic-rich lime mudstone formed at the same time.

Stage 3 (3,051-3,086.55 m): when the warm and wet climate becomes relatively warm and wet, the water is deep on the whole, and its high reducibility begins to reduce. The salinity increases slightly, and there are still a large number of organic matters. Due to the enhancement of evaporation, the lime sedimentation increases gradually, and the lithology primarily includes the dark gray lime-bearing mudstone and lime mudstone. The structural lenticle that is formed when the lime lamina composed of the calcite is broken by the windstorm can be discovered occasionally. There is also a weak bottom current during the sedimentary period. Therefore, the organic-rich lime-bearing mudstone and lime mudstone are mainly developed in this stage.

In conclusion, the lower submember of Member 3 of Shahejie Formation in FY-1 Well mainly develops the organicrich mudstone, lime-bearing mudstone and lime mudstone, and organic-contained argillaceous limestone/lime mudstone. The sedimentary environment undergoes the semideep, deep, and deep/semideep waters under the relatively dry-cold/relatively warm-wet, warm-wet, and warm-wet/relatively warmwet paleoclimates, respectively. The paleoredox transits from reducibility to high reducibility to high reducibility/reducibility, and the salinity changes in the sequence of saline water, brackish water, and brackish/saline water. Correspondingly, the paleoproductivity is low/relatively high, high, and relatively high in the three stages. According to the change of environmental factors and corresponding lithofacies assemblages, the organic-rich mudstone, lime-bearing mudstone, and lime mudstone are formed in the brackish and deep water under a warmwet/relatively warm-wet climate, while the organic-contained argillaceous limestone/lime mudstone and organic-rich lime mudstone are developed in the saline and semideep water under a relatively dry-cold/relatively warm-wet climate (Table 1 and Figure 6). This study shows that the abundance of organic matters is mainly controlled by the salinity, and the climate affects the lithology and sedimentary environment media conditions. When the environment experiences the relatively dry-cold/relatively warm-wet, warm-wet, and relatively warm-wet climates in the three stages, respectively, the water environment, organic matter content, and lithology will change accordingly.

\section{Conclusions}

By taking the lower submember of Member 3 in FY-1 Well, Dongying Sag, Bohai Bay Basin as the study object, this paper analyzes the vertical changes of sedimentary environment media conditions in this submember and elaborates how the environment of fine-grained sedimentary rocks controls the lithofacies development. The conclusions are as follows:

(1) The sedimentary environment media conditions underwent three phases. In Phase I when the climate was relatively dry and cold/relatively warm and wet, the water in the lake basin was shallow. When the climate was warm and wet in Phase II, the water deepened rapidly. When the climate was warm and wet/relatively warm and wet in Phase III, the water became deeper. Besides, the redox property transited three stages accordingly from reducibility to high reducibility to high reducibility/reducibility. The salinity that was high in Phase I decreased in Phase II and became low in Phase III. Paleoproductivity was low/relatively high at the beginning, then became high, and finally relatively high

(2) The change of sedimentary environment media conditions controls the lithofacies. Under an arid climate, the organic-contained argillaceous limestone and lime mudstone are developed better. When the climate becomes warm and wet, the organic-rich lime mudstone is formed. Under a warm-wet climate, the organic-rich lime-bearing mudstone and mudstone are developed best. When entering a relatively warmwet climate, the organic-rich lime-bearing mudstone and lime mudstone are developed better

(3) The abundance of organic matters is affected by the salinity, and the lithology and sedimentary environment media conditions are controlled by the climate. Meanwhile, climate is also a main reason for the change of lithology and sedimentary conditions. As the climate changes from the relatively dry-cold/relatively warm-wet to warm-wet, and ultimately warmwet, the sedimentary water environment, organic matter content, and lithology change accordingly

\section{Data Availability}

All data in the article is presented in the form of tables and graphs. All the data in this article is accessible to readers.

\section{Additional Points}

Highlights. (1) Sedimentological and geochemical indicators are combined to analyze the sedimentary environment evolution in the lower submember of Member 3 of Shahejie Formation in FY-1 Well of the Dongying Sag, which provides a reference for the study on the environmental evolution of lacustrine fine-grained sedimentary rocks. (2) The control effect of sedimentary environment on the lithofacies is discussed, which compensates for the paucity of research 
on their relationship, and plays a vital role in the muddy shale oil and gas exploration and the identification of favorable lithofacies. (3) The abundance of organic matters is controlled by the salinity, and climate is the primary cause of the sedimentary environment media condition change. Climate change can result in changes in sedimentary water environment, organic matter content, and lithology.

\section{Conflicts of Interest}

There are no conflicts of interest with respect to the results of this paper.

\section{Authors' Contributions}

The authors contributed equally to this work. All authors have read and agreed to the published version of the manuscript.

\section{Acknowledgments}

This study was supported by the Study on Astronomical Stratigraphic Period of Lacustrine Shale and High Resolution Sedimentary Cycle in Logging (41872166) of the National Natural Science Foundation of China and the Exploration and Development Research Institute, Shengli Oilfield Company, SINOPEC.

\section{References}

[1] A. C. Aplin and J. H. Macquaker, "Mudstone diversity: origin and implications for source, seal, and reservoir properties in petroleum systems," AAPG Bulletin, vol. 95, no. 12, pp. 2031-2059, 2011.

[2] Z. Jiang, C. Liang, J. Wu et al., "Several issues in sedimentological studies on hydrocarbon -bearing fine grained sedimentary rocks," Acta Petrolei Sinica, vol. 34, no. 6, p. 1032, 2013.

[3] J. Schieber, W. Zimmerle, and P. V. Sethi, Shales and Mudstones Volume 1: Basin Studies, Sedimentology and Paleontology, Schweizerbart'sche Verlagsbuchhandlung, Stuttgart, 1998.

[4] D. G. Hill, T. E. Lombardi, and J. P. Martin, "Fractured shale gas potential in New York," Northeastern Geology and Environmental Sciences, vol. 26, no. 1/2, pp. 57-78, 2004.

[5] S. L. Montgomery, D. M. Jarvie, K. A. Bowker, and R. M. Pollastro, "Mississippian Barnett Shale, Fort Worth basin, northCentral Texas: gas-shale play with multi-trillion cubic foot potential," AAPG Bulletin, vol. 89, no. 2, pp. 155-175, 2005.

[6] K. Zhang, C. Jia, Y. Song et al., "Analysis of Lower Cambrian shale gas composition, source and accumulation pattern in different tectonic backgrounds: a case study of Weiyuan block in the upper Yangtze region and Xiuwu Basin in the lower Yangtze region," Fuel, vol. 263, no. 2019, article 115978, 2020.

[7] O. R. Lazar, K. M. Bohacs, J. H. Macquaker, J. Schieber, and T. M. Demko, "Capturing key attributes of fine-grained sedimentary rocks in outcrops, cores, and thin sections: nomenclature and description guidelines," Journal of Sedimentary Research, vol. 85, no. 3, pp. 230-246, 2015.

[8] J. H. Macquaker and A. E. Adams, "Maximizing information from fine-grained sedimentary rocks: an inclusive nomenclature for mudstones," Journal of Sedimentary Research, vol. 73, no. 5, pp. 735-744, 2003.

[9] R. G. Loucks and S. C. Ruppel, "Mississippian Barnett Shale: lithofacies and depositional setting of a deep-water shale-gas succession in the Fort Worth Basin, Texas," AAPG Bulletin, vol. 91, no. 4, pp. 579-601, 2007.

[10] R. M. Slatt and N. D. Rodriguez, "Comparative sequence stratigraphy and organic geochemistry of gas shales: commonality or coincidence?," Journal of Natural Gas Science and Engineering, vol. 8, no. 8, pp. 68-84, 2012.

[11] M. Pommer and K. L. Milliken, "Pore types and pore-size distributions across thermal maturity, Eagle Ford Formation, southern Texas," AAPG Bulletin, vol. 99, no. 9, pp. 17131744, 2015.

[12] D. Yan, H. Wang, Q. L. Fu, Z. Chen, J. He, and Z. Gao, "Geochemical characteristics in the Longmaxi formation (early Silurian) of South China: implications for organic matter accumulation," Marine and Petroleum Geology, vol. 65, pp. 290301, 2015.

[13] H. A. Armstrong, B. R. Turner, I. M. Makhlouf et al., "Origin, sequence stratigraphy and depositional environment of an upper Ordovician (Hirnantian) deglacial black shale, Jordan," Palaeogeography, Palaeoclimatology, Palaeoecology, vol. 230, no. 3, pp. 352-355, 2006.

[14] Z. N. Yuri, V. G. Eder, and A. G. Zamirailova, "Composition and formation environments of the Upper Jurassic-Lower Cretaceous black shale Bazhenov formation (the central part of the West Siberian Basin)," Marine and Petroleum Geology, vol. 25, no. 3, pp. 289-306, 2008.

[15] A. M. Romero, Geochemical Characterization of the Woodford Shale, Central and Southeastern Oklahoma, The University of Oklahoma, Oklahoma, 2010.

[16] L. Guo, Z. Li, X. Xie et al., "High-frequency variation of geochemical elements and its geological implication on lacustrine organic-rich mudstone and shale formation: an example from the core-taking segment of well BY1 in the Biyang depression," Geoscience, vol. 29, no. 6, pp. 1360-1368, 2015, (in Chinese with English abstract).

[17] S. Pang, Y. Cao, and C. Liang, "Lithofacies characteristics and sedimentary environment of $\mathrm{Es}^{4 \mathrm{U}}$ and $\mathrm{Es}^{3 \mathrm{~L}}$ : a case study of well FY1 in Dongying sag, Bohai Bay Basin," Oil \& Gas Geology, vol. 40, no. 4, pp. 799-806, 2019, (in Chinese with English abstract).

[18] Y. Wang, H. Liu, G. Song et al., "Lacustrine shale fine-grained sedimentary system in Jiyang depression," Acta Petrolei Sinica, vol. 40, no. 4, pp. 395-410, 2019, (in Chinese with English abstract).

[19] Y. Shi, H. Ji, J. Yu, P. Xiang, Z. Yang, and D. Liu, "Provenance and sedimentary evolution from the Middle Permian to Early Triassic around the Bogda Mountain, nw China: a tectonic inversion responding to the consolidation of Pangea," Marine and Petroleum Geology, vol. 114, article 104169, 2020.

[20] Y. Shi, J. Wang, G. Zhang et al., “Tectono-climatic-sedimentary evolution and coupling mechanism during the middle Permian-early Triassic in Bogda area, Xinjiang," Journal of Palaeogeography (Chinese Edition), vol. 23, no. 2, pp. 389404, 2021, (in Chinese with English abstract).

[21] S. Sun, H. Liu, Y. Cao, S. Zhang, Y. Wang, and W. Yang, "Milankovitch cycle of lacustrine deepwater fine grained sedimentary rocks and its significance to shale oil: a case study of the upper Es4 member of well NY1 in Dongying sag," Journal of China of Mining \& Technology, vol. 46, no. 4, pp. 846-855, 2017, (in Chinese with English abstract).

[22] C. Liang, J. Zaixing, C. Yingchang, W. Jing, and H. Fang, "Sedimentary characteristics and origin of lacustrine organic-rich shales in the salinized Eocene Dongying depression," 
Geological Society of America Bulletin, vol. 130, no. 1, pp. 154174, 2017.

[23] C. Liang, Y. Cao, Z. Jiang, J. Wu, S. Guoqi, and Y. Wang, "Shale oil potential of lacustrine black shale in the Eocene Dongying depression: implications for geochemistry and reservoir characteristics," AAPG Bulletin, vol. 101, no. 11, pp. 1835-1858, 2017.

[24] Y. Ma, Lacustrine Shale Stratigraphy and Eocene Climate Recorded in the Jiyang Depression in East China, China University of Geosciences, 2017, (in Chinese with English abstract).

[25] Z. Chen, W. Jiang, L. Zhang, and M. Zha, "Organic matter, mineral composition, pore size, and gas sorption capacity of lacustrine mudstones: implications for the shale oil and gas exploration in the Dongying depression, eastern China," AAPG Bulletin, vol. 102, no. 8, pp. 1565-1600, 2018.

[26] B. Ma, K. A. Eriksson, Y. Cao, Y. Jia, Y. Wang, and B. C. Gill, "Fluid flow and related diagenetic processes in a rift basin: evidence from the fourth member of the Eocene Shahejie formation interval, Dongying depression, Bohai Bay Basin, China," AAPG Bulletin, vol. 100, no. 11, pp. 1633-1662, 2016.

[27] J. Wu, Z. Jiang, and X. Wang, "Sequence stratigraphy characteristics of lacustrine fine-grained sedimentary rocks: a case study of the upper fourth member of Paleogene Shahejie formation, Dongying sag, Bohai Bay Basin," Natural Gas Geoscience, vol. 29, no. 2, pp. 199-210, 2018, (in Chinese with English abstract).

[28] L. Gao, B. Sun, and Y. Wang, "Sedimentary characteristics and controlling factors of beach-bar sandstones of the upper section of the fourth member of Shahejie formation on the southern slope of Dongying sag, Bohai Bay Basin," Petroleum Geology \& Experiment, vol. 40, no. 5, pp. 669-675, 2018, (in Chinese with English abstract).

[29] M. Wang, J. Lu, Z. Zuo, H. Li, and B. Wang, "Characteristics and dominating factors of lamellar fine-grained sedimentary rocks: a case study of the upper $\mathrm{Es}_{4}$ member-lower $\mathrm{Es}_{3}$ member, Dongying sag, Bohai Bay Basin," Petroleum Geology \& Experiment, vol. 40, no. 4, pp. 470-478, 2018, (in Chinese with English abstract).

[30] C. Lampe, G. Song, L. Cong, and X. Mu, "Fault control on hydrocarbon migration and accumulation in the Tertiary Dongying depression, Bohai Basin, China," AAPG Bulletin, vol. 96, no. 6, pp. 983-1000, 2012.

[31] C. Liang, Z. Jiang, Y. Cao, M. Wu, L. Guo, and C. Zhang, "Deep-water depositional mechanisms and significance for unconventional hydrocarbon exploration: a case study from the lower Silurian Longmaxi shale in the southeastern Sichuan Basin," AAPG Bulletin, vol. 100, no. 5, pp. 773-794, 2016.

[32] Z. Li, W. Yang, Y. Wang et al., "Anatomy of a lacustrine stratigraphic sequence within the fourth member of the Eocene Shahejie formation along the steep margin of the Dongying depression, eastern China," AAPG Bulletin, vol. 103, no. 2, pp. 469-504, 2019.

[33] Analytical Methods Committee and Royal Society of Chemistry, "Evaluation of analytical instrumentation. Part XXIII. Instrumentation for portable X-ray fluorescence spectrometry," Accreditation and Quality Assurance, vol. 13, no. 8, pp. 453-464, 2008.

[34] S. Li, R. Zhu, J. Cui, Z. Luo, H. Jiao, and H. Liu, "Sedimentary characteristics of fine-grained sedimentary rock and paleoenvironment of Chang 7 member in the Ordos Basin: a case study from well Yaoye 1 in Tongchuan," Acta Sedimentologica
Sinica, vol. 38, no. 3, pp. 1-13, 2019, (in Chinese with English abstract).

[35] J. Wang, F. Tan, and X. Fu, "Sedimentary rock work method," Beijing: Geological Publishing House, vol. 18, p. 28, 2015, (in Chinese with English abstract).

[36] K. Zhao, Characteristics and Genesis Analysis of Carbonate lamina in the Upper Fourth Member and the Lower Third Member of Shahejie Formation in Dongying Depression, China University of Geosciences, Wuhan, Bohai Bay Basin, 2019, (in Chinese with English abstract).

[37] Y. Wang, G. Song, H. Liu et al., "Formation environment and sedimentary structures of fine grained sedimentary rock in Jiyang depression," Journal of Northeast Petroleum University, vol. 39, no. 3, pp. 7-14, 2015, (in Chinese with English abstract).

[38] J. P. Smol and B. F. Cumming, "Tracking long-term changes in climate using algal indicators in lake sediments," Journal of Phycology, vol. 36, no. 6, pp. 986-1011, 2000.

[39] A. M. Bloom, K. A. Moser, D. F. Porinchu, and G. M. Macdonald, "Diatom-inference models for surface-water temperature and salinity developed from a 57-lake calibration set from the Sierra Nevada, California, USA," Journal of Paleolimnology, vol. 29, no. 2, pp. 235-255, 2003.

[40] L. Peng, Y. Lu, P. Peng et al., "Heterogeneity and evolution model of the lower Shahejie member 3 mud-shale in the Bonan subsag, Bohai Bay Basin: an example from well Luo 69," Oil \& Gas Geology, vol. 38, no. 2, pp. 219-227, 2017, (in Chinese with English abstract).

[41] J. Wu, Z. Jiang, J. Tong, L. Yang, J. Li, and H. Nie, "Sedimentary environment and control factors of fine grained sedimentary rocks in the upper fourth member of Paleogene Shahejie formation, Dongying sag," Acta Petrolei Sinica, vol. 37, no. 4, pp. 464-473, 2016, (in Chinese with English abstract).

[42] J. Wu, Z. Jiang, and C. Liang, "Lithofacies characteristics of fine grained sedimentary rocks in the upper submember of member 4 of Shahejie formation, Dongying sag and their relationship with sedimentary environment," Acta Petrolei Sinica, vol. 38, no. 10, pp. 1110-1120, 2017, (in Chinese with English abstract).

[43] S. Liu, Y. Cao, and C. Liang, "Lithologic characteristics and sedimentary environment of fine-grained sedimentary rocks of the Paleogene in Dongying sag, Bohai Bay Basin," Journal of Palaeogeography, vol. 21, no. 3, pp. 479-488, 2019, (in Chinese with English abstract).

[44] W. Yang, X. Wang, Y. Jiang et al., "Quantitative reconstruction of paleoclimate and its effects on fine-grained lacustrine sediments: a case study of the upper $\mathrm{Es}_{4}$ and lower $\mathrm{Es}_{3}$ in Dongying sag," Petroleum Geology and Recovery Efficiency, vol. 25, no. 2, pp. 29-35, 2018, (in Chinese with English abstract).

[45] W. Yang, Y. Jiang, and Y. Wang, "Study on shale facies sedimentary environment of lower $\mathrm{Es}_{3}$-upper $\mathrm{Es}_{4}$ in Dongying sag," Journal of China University of Petroleum, vol. 39, no. 4, pp. 19-25, 2015, (in Chinese with English abstract).

[46] W. A. Yong, W. A. Xuejun, S. O. Guoqi et al., "Genetic connection between mud shale lithofacies and shale oil enrichment in Jiyang depression, Bohai Bay Basin," Petroleum Exploration and Development, vol. 43, no. 5, pp. 696-704, 2016, (in Chinese with English abstract).

[47] Y. Wang, H. M. Liu, G. Q. Song et al., "Carbonate genesis and geological significance of shale hydrocarbon in lacustrine facies mud shale: a case study of source rocks in the upper submember of member 4 and lower submember of member 3 of 
Shahejie formation, Dongying sag," Acta Petrolei Sinica, vol. 38, no. 12, pp. 1390-1399, 2017, (in Chinese with English abstract).

[48] S. J. Davies and T. Elliott, "Spectral gamma ray characterization of high resolution sequence stratigraphy: examples from Upper Carboniferous fluvio-deltaic systems, County Clare, Ireland," Geological Society, London, Special Publications, vol. 104, no. 1, pp. 25-35, 1996.

[49] R. M. Slatt, P. R. Philp, Y. Abousleiman et al., "Pore-toregional-scale integrated characterization workflow for unconventional gas shales," in Shale Reservoirs: Giant Resources for the 21st Century, AAPG Memoir 97, J. A. Breyer, Ed., American As-sociation of Petroleum Geologists, Tulsa, OK, 2012.

[50] X. Du, H. Liu, H. Liu et al., "Methods of sequence stratigraphy in the fine-grained sediments: a case from the upper fourth sub-member and the lower third sub-member of the Shahejie formation in well Fanye 1 of Dongying depression," Geological Science and Technology Information, vol. 35, no. 4, pp. 1-10, 2016, (in Chinese with English abstract).

[51] Q. Liu, X. Zeng, X. Wang, and J. Cai, "Lithofacies of mudstone and shale deposits of the $\mathrm{Es}^{3} \mathrm{z}$-Es ${ }^{4} \mathrm{~s}$ formation in Dongying sag and their depositional environment," Marine Geology \& Quaternary Geology, vol. 37, no. 3, pp. 147-156, 2017, (in Chinese with English abstract).

[52] Y. Zheng, R. F. Anderson, A. van Geen, and J. S. Kuwabara, "Authigenic molybdenum formation in marine sediments: a link to pore water sulfide in the Santa Barbara Basin," Geochimica et Cosmochimica Acta, vol. 64, no. 24, pp. 4165-4178, 2000.

[53] T. J. Nameroff, S. E. Calvert, and J. W. Murray, "Glacial-interglacial variability in the eastern tropical North Pacific oxygen minimum zone recorded by redox-sensitive trace metals," Paleoceanography, vol. 19, no. 1, pp. 1-19, 2004.

[54] T. J. Algeo and J. B. Maynard, "Trace-element behavior and redox facies in core shales of upper Pennsylvanian Kansastype cyclothems," Chemical Geology, vol. 206, no. 3-4, pp. 289-318, 2004.

[55] D. Z. Piper and R. B. Perkins, "A modern vs. Permian black shale-the hydrography, primary productivity, and watercolumn chemistry of deposition," Chemical Geology, vol. 206, no. 3-4, pp. 177-197, 2004.

[56] J. N. Pattan, N. J. Pearce, and P. G. Mislankar, "Constraints in using cerium-anomaly of bulk sediments as an indicator of paleo bottom water redox environment: a case study from the Central Indian Ocean Basin," Chemical Geology, vol. 221, no. 3-4, pp. 260-278, 2005.

[57] G. Xiong, X. Jiang, X. Cai, and H. Wu, "The characteristics of trace element and REE geochemistry of the cretaceous mudrocks and shales from southern Tibet and its analysis of redox condition," Advances in Earth Science, vol. 25, no. 7, pp. 730-745, 2010, (in Chinese with English abstract).

[58] Z. Yong, X. Zhang, and H. Deng, "Differences about organic matter enrichment in the shale section of Ediacaran Doushantuo formation in West Hubei of China," Journal of Chengdu University of Technology (Science \& Technology Edition), vol. 39, no. 6, pp. 567-574, 2012, (in Chinese with English abstract).

[59] S. Wang, D. Dong, Y. Wang, J. Huang, and B. Pu, "Geochemistry evaluation index of redox-sensitive elements for depositional environments of Silurian Longmaxi organic-rich shale in the south of Sichuan Basin," Marine Origin Petroleum Geol- ogy, vol. 73, no. 3, pp. 27-34, 2014, (in Chinese with English abstract).

[60] Q. Du, S. Guo, X. Shen, Z. Cao, X. Zhang, and Y. Li, "Palaeowater characteristics of the member 1 of Paleogene Shahejie formation in southern Nanpu sag, Bohai Bay Basin," Journal of Palaeogeography, vol. 18, no. 2, pp. 173-183, 2016, (in Chinese with English abstract).

[61] F. Wang, X. Liu, X. Deng et al., "Geochemical characteristics and environmental implications of trace elements of Zhifang formation in Ordos Basin," Acta Sedimentologica Sinica, vol. 35, no. 6, pp. 1265-1273, 2017, (in Chinese with English abstract).

[62] K. Zhang, Z. Li, S. Jiang et al., "Comparative analysis of the siliceous source and organic matter enrichment mechanism of the Upper Ordovician-Lower Silurian shale in the upperlower Yangtze area," Minerals, vol. 8, no. 7, p. 283, 2018.

[63] K. Zhang, Y. Song, S. Jiang et al., "Mechanism analysis of organic matter enrichment in different sedimentary backgrounds: a case study of the Lower Cambrian and the Upper Ordovician-Lower Silurian, in Yangtze region," Marine and Petroleum Geology, vol. 99, pp. 488-497, 2019.

[64] E. Custodio, "Aquifer overexploitation: what does it mean?," Hydrogeology Journal, vol. 10, no. 2, pp. 254-277, 2002.

[65] J. Xu, R. Pu, L. Yang, and A. Li, "The palaeosalinity analysis of carboniferous mudstone, Tarim Basin," Acta Sedimentologica Sinica, vol. 28, no. 3, pp. 509-517, 2010, (in Chinese with English abstract).

[66] X. Peng, L. Wang, and L. Jiang, "Geochemical characteristics of the Lucaogou formation oil shale in the southeastern margin of the Junggar Basin and its environmental implications," Bulletin of Mineralogy, Petrology and Geochemistry, vol. 31, no. 2, pp. 121-127, 2012, (in Chinese with English abstract).

[67] X. Tan, J. Tian, J. Huang, X. Lin, and J. Ma, "Material responses and accumulation patterns in cyclic sediment records of continental clastic rocks: taking the Paleogene Kongdian formation of Wangiiagang area in Jiyang depression as an example," Oil \& Gas Geology, vol. 34, no. 3, pp. 332-341, 2013, (in Chinese with English abstract).

[68] S. Zhang, S. Chen, S. Cui et al., "Characteristics and types of fine-grained sedimentary rocks lithofacies insemi-deep and deep lacustrine, Dongying sag," Journal of China University of Petroleum(Edition of Natural Science), vol. 38, no. 5, pp. 9-17, 2014, (in Chinese with English abstract).

[69] Y. Fu, L. Shao, L. Zhang et al., "Geochemical characteristics of mudstones in the Permo-Carboniferous strata of the Jiaozuo coalfield and their paleoenvironmental significance," Acta Sedimentologica Sinica, vol. 36, no. 2, pp. 415-426, 2018, (in Chinese with English abstract).

[70] J. Schieber, "Facies and origin of shales from the midProterozoic Newland Formation, Belt Basin, Montana, USA," Sedimentology, vol. 36, no. 2, pp. 203-219, 1989.

[71] S. Zhang, H. Liu, S. Chen et al., "Classification scheme for lithofacies of fine grained sedimentary rocks in faulted basins of eastern China: insights from the fine grained sedimentary rocks in Paleogene, southern Bohai Bay Basin," Acta Geologica Sinica, vol. 91, no. 5, pp. 1108-1119, 2017, (in Chinese with English abstract).

[72] S. Angulo and L. Buatois, "Integrating depositional models, ichnology, and sequence stratigraphy in reservoir characterization: the middle member of the Devonian-Carboniferous Bakken formation of subsurface southeastern Saskatchewan revisited," AAPG Bulletin, vol. 96, no. 6, pp. 1017-1043, 2012. 
[73] D. Bonar and M. D. Sacchi, "Denoising seismic data using the nonlocal means algorithm," Geophysics, vol. 77, no. 1, pp. A5A8, 2012.

[74] J. Ochoa, J. M. Wolak, and M. H. Gardner, "Recognition criteria for distinguishing between hemipelagic and pelagic mudrocks in the characterization of deep-water reservoir heterogeneity," AAPG Bulletin, vol. 97, no. 10, pp. 1785-1803, 2013.

[75] S. F. Konitzer, S. J. Davies, M. H. Stephenson, and M. J. Leng, "Depositional controls on mudstone lithofacies in a basinal setting: implications for the delivery of sedimentary organic matter," Journal of Sedimentary Research, vol. 84, no. 3, pp. 198-214, 2014.

[76] J. Zhang, Z. Jiang, X. Jiang, S. Wang, C. Liang, and M. Wu, “Oil generation induces sparry calcite formation in lacustrine mudrock, Eocene of east China," Marine and Petroleum Geology, vol. 71, pp. 344-359, 2016.

[77] J. Peng, T. Xu, and L. Yu, "Sedimentary characteristics and controlling factors of lacustrine fine-grained rocks of the fourth member of Shahejie formation in Dongying depression," Lithologic Reservoirs, vol. 32, no. 5, pp. 1-11, 2020. 